\title{
Greenhouse gas emissions in coffee grown with differing input levels under conventional and organic management
}

Martin R.A. Noponen ${ }^{a b, 1}$, Gareth Edwards-Jones ${ }^{a e}$, Jeremy P. Haggar ${ }^{b c}$, Gabriela Soto ${ }^{b}$, Nicola Attarzadeh $^{a d}$, John R. Healey ${ }^{a}$

${ }^{a}$ School of Environment, Natural Resource and Geography, Bangor University, Bangor, Gwynedd, LL57 2UW, United Kingdom

${ }^{b}$ Centro Agronómico Tropical de Investigación y Enseñanza (CATIE), Turrialba, CATIE 7170, Costa Rica

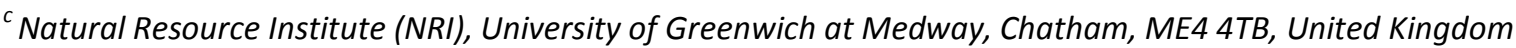

${ }^{d}$ CarbonRoots, York YO3O 7DN, United Kingdom

${ }^{e}$ Deceased

Keywords: Agroforestry systems; Carbon footprinting; Climate change; Coffee; Nitrous oxide.

\begin{abstract}
Coffee plays a key role in sustaining millions of livelihoods around the world. Understanding GHG emissions from coffee supply chains is important in evaluating options for climate change mitigation within the sector. We use data from two long-term coffee agroforestry experiments in Costa Rica and Nicaragua to calculate carbon footprints (CF) for coffee and identify emission hotspots within different management systems, levels of inputs and shade types. Management system and input level were the main cause of variation in CFs. Carbon footprints for $1 \mathrm{~kg}$ of fresh coffee cherries were between 0.26 and $0.67 \mathrm{kgCO}_{2} \mathrm{e}$ for conventional and 0.12 and $0.52 \mathrm{kgCO}_{2} \mathrm{e}$ for organic management systems. The main contributor to GHG emissions for all management systems was the inputs of organic and inorganic nitrogen. Nitrous oxide emissions from pruning inputs contributed between $7 \%$ and $42 \%$ of CFs. However, these estimates were strongly influenced by the choice of emission
\end{abstract}

\footnotetext{
${ }^{1}$ Corresponding author. Current address: School of the Environment and Natural Resource and Geography, Bangor University, Bangor, Gwynedd, LL57 2UW, United Kingdom. Tel.: +44 1904399860 E-mail address: $\underline{\text { m.noponen@bangor.ac.uk }}$
} 
factor used in the calculations. Research is required to develop emission factors that account for different qualities and management of nitrogen inputs to enable effective calculation of the CF from different management strategies, and especially from the pruning and organic inputs managed in agroforestry systems. As such, effective climate change mitigation strategies can only be developed from site-specific studies which utilise accurate accounting and regional-specific emission factors.

\section{Introduction}

The need for sustainable intensification of food production has recently been emphasised in the development of global food policy (Foresight, 2011). Given the likely impacts of climate change and rising human populations (UN 2009), a key challenge for achieving such sustainable intensification is to develop farming systems which produce increased yields without associated increases in greenhouse gas (GHG) emissions. In order to achieve this aim there is a need to fully understand the types and amounts of GHGs that are emitted by different food production systems.

Product carbon footprinting (PCF) (often referred to as 'carbon footprinting' (CF)) is commonly used to calculate the GHG emissions released from food supply chains. Developing a CF has some similarities to developing a life cycle assessment (LCA), and many of the CF methods currently in use are based upon the ISO method for Life Cycle Assessment, ISO 14040/44 (e.g., the GHG Protocol's draft Product Life Cycle Accounting and Reporting Standard (World Resources Institute \& World Business Council for Sustainable Development, 2009) and the British Standard Institute's Publically Available Specification 2050:2008 (hereafter referred to as PAS 2050) for assessment of the life-cycle greenhouse gas emissions of goods and services (BSI, 2008)). Both the draft GHG Protocol method and PAS 2050 have been developed in response to a call for standardised and transparent CF methods, as ISO 14040 and 14044 have been criticised for being flexible in their approach and therefore open to some interpretation in application (Plassmann et al., 2010). By maintaining consistency in the calculation method it should be possible to compare the 
CFs of different supply chains, thus enabling identification of systems with lower GHG emissions per unit of production.

A number of problems, however, exist with the methods currently used for making CF calculations, most notably the fact that despite the calls for consistency, different CF schemes do adopt different analytical methods (Bolwig and Gibbon, 2009; Plassmann et al., 2010). For example, Plassmann et al. (2010) found that the CF of a kilogram of sugar can vary by up to $1900 \%$ when calculated by different CF methods. By far the greatest contributor to CF variation was the treatment of land use change emissions (emissions released during the conversion of non-agricultural land to agriculture). This is of concern for agricultural production in developing countries, where contemporary conversion of land use from non-agricultural tree-dominated to agriculture is more likely than in developed countries, and where few data currently exist to enable the accurate calculation of these emissions (Brenton et al., 2009; Plassmann et al., 2010).

A second problem associated with CFs relates to the availability of relevant emission factors (EFs). In essence, CFs are calculated by multiplying the quantities of all inputs which contribute to a product's life cycle (e.g. kg fertilisers, kWh electricity, litres diesel) by their relative EF, and summing these emissions together to form the total CF. Emission factors represent the contribution of a product or process to global warming, and are expressed in units of carbon dioxide equivalents $\left(\mathrm{CO}_{2} \mathrm{e}\right)$. Emission factors are published in commercial databases and the scientific literature, but as the majority of CF research and method-development to-date has taken place within industrialised countries there is a lack of location-specific EFs for many production systems that occur in less industrialised countries, e.g. coffee. This is a major challenge for understanding the levels of emissions from these regions. As one of the most traded commodities in the world and with over 10 million hectares of land devoted to its production (FAO, 2011), coffee continues to be one of the most widely grown cash crops, sustaining the livelihoods of up to 25 million people globally (IIED, 1997). As a result, the coffee supply chain is an important contributor to global GHG emissions. However, whilst a major emission hotspot within the coffee supply chain has been found to lie within the production of 
coffee at the farm level (PCF Pilotprojekt Deutschland, 2008), its GHG emissions remains relatively understudied (Hergoualc'h et al., 2008; Verchot et al., 2006). Against this background the present study uses PAS 2050:2008 and IPCC CF methods to (i) estimate the relative GHG emissions from different levels of management and material inputs (high versus moderate) and from different types of input (organic versus conventional production systems), (ii) identify the greatest source of GHG emissions from each system (their "emission hotspots") and (iii) determine the effects of uncertainty in EF on the overall CF. Results from studies such as this should make an important contribution to quantifying global GHG emissions from agricultural production and designing sustainable and efficient systems that can meet human needs with a reduced environmental impact.

\section{Methods}

\subsection{Site description}

The research was conducted at two 3-ha field sites, in Costa Rica and Nicaragua respectively, chosen to represent low altitude coffee growing regions, and both managed by the 'Centro Agronómico Tropical de Investigación y Enseñanza' (CATIE). Both sites were established at the end of 2000. The Costa Rica site is located in Turrialba $\left(9^{\circ} 53^{\prime} 44^{\prime \prime} \mathrm{N}, 83^{\circ} 40^{\prime} 7^{\prime \prime} \mathrm{W}\right)$ at $685 \mathrm{~m}$ above sea level. The climate is humid tropical with no marked dry season: annual precipitation is $2600 \mathrm{~mm} \mathrm{yr}^{-1}$ and annual mean temperature is $22{ }^{\circ} \mathrm{C}$ (Haggar et al., 2011). Two soil types have been identified at the site and classified as Typic Endoaquepts and Typic Endoaquults under the USDA Soil Taxonomy classification system (Soil Survey Staff, 1999); both are poorly drained. The previous land-use was sugar cane cultivation. For establishment of the current experiment, the site was prepared with extensive drainage channels of up to $1.5 \mathrm{~m}$ in depth. The coffee cultivar Coffea arabica L. 'Caturra' was planted. The Nicaragua site is located in Masatepe $\left(11^{\circ} 53^{\prime} 54^{\prime \prime} \mathrm{N}, 86^{\circ} 08^{\prime} 56^{\prime \prime} \mathrm{W}\right)$ at $455 \mathrm{~m}$ above sea level. The climate is semi-dry tropical with a distinct rainy season between May and November: mean annual rainfall is $1386 \mathrm{~mm}$ and mean annual temperature is $24{ }^{\circ} \mathrm{C}$ (Haggar et al., 2011). Two soil types have been identified at the site and classified as Andisols or Andosols (Humic Durustands 
and Humic Haplustands) under the USDA Soil Taxonomy classification system (Soil Survey Staff, 1999). The previous land-use was long-established shaded coffee. In the experiment, the coffee cultivar planted was Coffea arabica var. 'Pacas'. A more detailed description of the experiments and their productivity is reported elsewhere (Haggar et al., 2011).

\subsection{Experimental design}

The experiments were set up to study the ecological efficiencies of coffee production. A main aim is to compare organic and conventional coffee production systems under various types of shade. The five main-plot treatments at each site are full sun and four different individual species or combinations of shade tree (Table 1). The four sub-plot treatments are systems combining the two different types and levels of nutrient and pest management inputs (Table 3 ). The tree species used in the experiment (Table 2) are selected from those most commonly grown in association with coffee production in the two regions. The design is a randomized block with three blocks per site, each containing one replicate of each treatment combination. An incomplete factorial design comprising 14 of the potential 20 main-plot/sub-plot treatment combinations at each site was chosen as some combinations are not representative of real farming systems (e.g. full sun with organic management, Table 1). The sub-plots range in size between 500 and $800 \mathrm{~m}^{2}$ including borders. Coffee bushes were planted at a density of 4000 and 5000 plants per ha in Nicaragua and Costa Rica respectively which did not differ amongst the main-plot or sub-plot treatments. Shade trees were planted in 2000 at a density of 416 and 667 trees per ha ${ }^{-1}$ in Costa Rica and Nicaragua respectively but have since been progressively thinned and pruned to achieve a uniform shade level (Table 1).

The tree management regime varied according to species; Erythrina poeppigiana in Costa Rica and Inga laurina in Nicaragua (both Leguminosae) were pruned for the management of shade and to provide organic matter (including $\mathrm{N}$ ) input to soil. All E. poeppigiana trees were heavily pruned twice per year and their prunings left on the ground. In the conventional intensive $(\mathrm{Cl})$ sub-plot treatments of E. poeppigiana, trees were pruned at a height of 1.8-2.0 $\mathrm{m}$ with the removal of all branches above 
this height (pollarding). This practice is frequently found in conventional high-intensity coffee agroforestry systems in Costa Rica. In the other three sub-plot treatments, however, E. poeppigiana trees were managed according to the recommendations of Muschler (2001) whereby trees were pruned at a height of around $4 \mathrm{~m}$ and a minimum of three branches were left for partial shade cover. In Nicaragua, I. laurina was managed to create a homogeneous canopy cover of approximately $40 \%$, through annual pruning of branches at any height, accounting for overall smaller pruning residue inputs compared with E. poepiggiana in Costa Rica. In contrast, the timber tree species were managed to promote the development of a straight trunk and thus maximise timber value but were not subjected to a systematic pruning regime. Trunks and major branches of thinned and pruned timber trees were removed from the plots whereas leaf and small branch material was left as an organic amendment. All the material pruned from coffee bushes was also left in the plots (coffee bushes were pruned according to standard coffee agronomic practice, to the same level across all treatments).

\subsection{Calculation of carbon footprints}

PAS 2050 (BSI, 2008) is the only transparent and publically available product CF method published to-date and has therefore been chosen here for all CF calculations. Within this method, all GHGs (including $\mathrm{CO}_{2}, \mathrm{~N}_{2} \mathrm{O}$ and $\left.\mathrm{CH}_{4}\right)$ are accounted for and converted into units of $\mathrm{CO}_{2}$-equivalents $\left(\mathrm{CO}_{2} \mathrm{e}\right)$ according to their global warming potential (GWP) over 100 years. All GHG emissions associated with the provision and use of raw materials and energy are included in the calculation. Capital goods, human energy inputs such as manual labour, transport of employees to and from the workplace and animals providing transport are excluded from PAS 2050.

Of specific relevance to agricultural $\mathrm{CFs}$ are non- $\mathrm{CO}_{2}$ emissions from livestock, their manure and soils, which must be included, calculated according to IPCC Guidelines for National GHG Inventories (De Klein et al., 2006). Nitrous oxide emissions from soils are accounted for by including direct and indirect emissions resulting from $\mathrm{N}$ additions, deposition and leaching. As all land under study here 
was in agricultural production prior to 1990, no direct emissions from land use change (LUC) have been included. Changes in soil carbon, either as emissions, sequestration or in eroded material, are excluded from PAS 2050 unless they are a direct result of LUC activities. Carbon stored in living organisms such as trees or perennial crops is excluded from the PAS 2050 method; therefore if LUC results in net carbon storage, no recognition is given by way of a reduced CF. Although this is of particular relevance to agroforestry systems with perennial crops such as coffee, which have been shown to provide long-term carbon stores in shade-tree and crop biomass (Segura et al., 2006; Dossa et al., 2008), currently these gain no recognition for their net carbon storage benefit when compared, for example, with coffee grown in full sun or with annual crops.

\subsection{Data Collection}

As the aim of this study is to compare emissions from different farming methods, the system boundaries were drawn at the farm gate, including only those emissions directly associated with the production and management of a particular system. Carbon footprint calculations for each system were based on annualised averages of all inputs and yields since the second year of coffee production, to best represent the different production systems. The functional unit (unit of production) was set at $1 \mathrm{~kg}$ of non-processed fresh coffee cherries.

Data on coffee yields, management and material inputs were recorded for all sub-plot treatments. For both conventional managements (Table 3), emissions from the production of inorganic fertilisers and pesticides were extracted from the Ecoinvent database (Nemecek et al., 2007). For all four subplot management treatments, only commercial fertiliser and pesticide products were assigned production emissions; PAS 2050 states that emissions should be assigned according to a product's economic value rather than its mass, thus the production emission from one industry (e.g. chicken farming) should be partitioned between its products (e.g. chicken meat and manure) according to their respective commercial values. In the case of these coffee production systems, however, organic fertilisers such as chicken manure and coffee pulp were assumed to be waste products of 
another industry with no economic value, and thus were assigned no production emissions. Furthermore, although data on GHG emissions from poultry manure can be found within the Ecoinvent database, we considered these values excessive for this study as the database values include processing emissions from drying, granulation and packaging (Nemecek et al., 2007) which are not part of the manure production process in Costa Rica or Nicaragua.

Emissions were calculated for the transportation of materials and fertilisers from their place of purchase to the on-farm experimental sites; to allow for comparability a default transport distance of $10 \mathrm{~km}$ was chosen for both sites. Emissions arising from the production and use of fuels such as gasoline and lubricants, used mostly for weed control, and materials and sundries used in the farm management of the experimental sites were also included in the calculations. Emission factors for the production and manufacturing processes of individual inputs were obtained from the publically available database of the Renewable Fuels Agency (RFA) and Ecoinvent (Althaus et al., 2007; Classen et al., 2009). Costa Rica-specific EFs for diesel and gasoline were sourced from a report used in the Costa Rican national GHG inventory (Ministerio de Ambiente y Energía de Costa Rica, 2007) and used for both countries' footprints. No electricity was consumed in the on-farm operations.

For calculating $\mathrm{N}_{2} \mathrm{O}$ emissions from soil we followed IPCC Good Practice Guidelines for calculating GHG emissions (De Klein et al., 2006) and chose a regional-specific EF (Table 1) from Costa Rica for N fertiliser application of $1 \%$ for timber-tree and full-sun coffee production systems established by Hergoualc'h et al. (2008), 1.2\% for leguminous-shade systems and a value from the same study of $0.3 \%$ for $\mathrm{N}$ applications from pruning inputs (Hergoualc'h pers. comm.). To assess the effects of using different EF's on the overall CF we compared the results of (i) using the IPCC tier 1 default value of $1 \%$ for all $\mathrm{N}$ inputs (scenario 1) (De Klein et al., 2006), (ii) using a region-specific EF (scenario 2) and (iii) excluding emissions from pruning inputs (scenario 3) (Hergoualc'h et al., 2008). $\mathrm{N}$ contents of pruning residues, needed to calculate soil $\mathrm{N}_{2} \mathrm{O}$ emissions, were obtained from analyses carried out at the Laboratorio de Análisis de Suelos, Tejido Vegetal y Aguas at CATIE, in Costa Rica. 
Table 1 Main-plot (shade tree combinations) and sub-plot (management inputs) treatments at the experimental sites in a) Costa Rica and b) Nicaragua. Sub-plot treatment abbreviations are given in table 3.

a) Costa Rica

\begin{tabular}{|c|c|c|c|c|c|c|c|c|c|c|}
\hline & & & & & & Nicarag & & & & \\
\hline Main-plot treatments & Full sun & $\begin{array}{c}\text { Erythrina } \\
\text { poeppigiana }\end{array}$ & $\begin{array}{l}\text { Terminalia } \\
\text { amazonia }\end{array}$ & $\begin{array}{c}\text { Chloroleucon } \\
\text { eurycyclum }\end{array}$ & $\begin{array}{c}\text { Erythrina } \\
\text { poeppigiana/ } \\
\text { Terminalia } \\
\text { amazonia } \\
\text { ET }\end{array}$ & $\begin{array}{l}\text { Full } \\
\text { sun } \\
\text { FS }\end{array}$ & $\begin{array}{l}\text { Simarouba } \\
\text { glauca/ } \\
\text { Tabebuia } \\
\text { rosea } \\
\text { SGTR }\end{array}$ & $\begin{array}{l}\text { Samanea } \\
\text { saman/ } \\
\text { Tabebuia } \\
\text { rosea } \\
\text { SSTR }\end{array}$ & $\begin{array}{l}\text { Inga } \\
\text { laurina/ } \\
\text { Simarouba } \\
\text { glauca } \\
\text { ILSG }\end{array}$ & $\begin{array}{c}\text { Inga } \\
\text { laurina/ } \\
\text { Samanea } \\
\text { saman } \\
\text { ILSS }\end{array}$ \\
\hline Sub-plot treatments & $\mathrm{CM}^{1}, \mathrm{CI}$ & $\begin{array}{l}\text { OM, OI, } \\
\text { CM, CI }\end{array}$ & $\begin{array}{l}\text { OM, OI, } \\
\text { CM, CI }\end{array}$ & $\mathrm{OI}, \mathrm{CM}$ & $\mathrm{OI}, \mathrm{CM}$ & $\mathrm{CM}, \mathrm{CI}$ & $\begin{array}{l}\text { OM, OI, } \\
\text { CM, CI }\end{array}$ & $\mathrm{OI}, \mathrm{CM}$ & $\mathrm{OI}, \mathrm{CM}$ & $\begin{array}{l}\text { OM, OI, } \\
\text { CM, CI }\end{array}$ \\
\hline Shade tree density $\left(\mathrm{ha}^{-1}\right)$ & -2 & $269^{3} / 583^{4}$ & 216 & 257 & 231 & -2 & 286 & 331 & 336 & 376 \\
\hline $\begin{array}{l}\text { Emission factor for } \mathrm{N} \\
\text { inputs (excluding } \\
\text { pruning) }\end{array}$ & $1 \%$ & $1.2 \%$ & $1 \%$ & $1.2 \%$ & $1.2 \%$ & $1 \%$ & $1 \%$ & $1.2 \%$ & $1.2 \%$ & $1.2 \%$ \\
\hline
\end{tabular}

${ }^{1}$ Subplot treatments are shown in full in Table $3 ;{ }^{2}$ no shade trees are present in full sun treatments; ${ }^{3}$ densities for OM, OI and $\mathrm{CM}$ sub-plot treatments; ${ }^{4}$ densities for $\mathrm{Cl}$ sub-plot treatment

Table 2 Shade tree species used in the main-plot experimental treatments in the sites in Costa Rica and Nicaragua

\section{a) Costa Rica}

\begin{tabular}{|c|c|c|c|c|c|c|c|}
\hline Species & $\begin{array}{l}\text { Terminalia } \\
\text { amazonia } \\
\text { (J.F. Gmel.) Exell }\end{array}$ & $\begin{array}{l}\text { Chloroleucon } \\
\text { eurycyclum } \\
\text { Barneby \& J.W. } \\
\text { Grimes }\end{array}$ & $\begin{array}{l}\text { Erythrina } \\
\text { poeppigiana } \\
\text { (Walp.) O.F. Cook }\end{array}$ & $\begin{array}{l}\text { Inga laurina } \\
\text { (Sw.) Willd. }\end{array}$ & $\begin{array}{l}\text { Samanea saman } \\
\text { (Jacq.) Merr. }\end{array}$ & $\begin{array}{l}\text { Simarouba glauca } \\
\text { DC. }\end{array}$ & $\begin{array}{l}\text { Tabebuia rosea } \\
\text { (Bertol.) DC. }\end{array}$ \\
\hline Phenology & evergreen & evergreen & evergreen & evergreen & evergreen & evergreen & deciduous \\
\hline $\mathrm{N}$-fixer & no & yes & yes & yes & yes & no & no \\
\hline Dominant use & timber $^{1}$ & timber $^{1}$ & service $^{2}$ & service $^{2}$ & timber $^{1}$ & timber $^{1}$ & timber $^{1}$ \\
\hline
\end{tabular}

\section{b) Nicaragua}

\footnotetext{
'timber' = shade trees that are managed for their timber; ${ }^{2}$ service' = shade trees that are managed for their 'services' to coffee production, e.g. N-fixation, organic matter inputs
} 
Table 3 Experimental sub-plot coffee management treatments in the sites in Costa Rica and Nicaragua.

\begin{tabular}{|c|c|c|c|c|}
\hline Name of sub-treatment & Organic Moderate & Organic Intensive & Conventional Moderate & Conventional Intensive \\
\hline Abbreviation & $\mathrm{OM}$ & Ol & $\mathrm{CM}$ & $\mathrm{Cl}$ \\
\hline Soil amendments ${ }^{1}$ & $\begin{array}{l}\text { Organic-coffee pulp } \\
\left(\mathrm{kg}^{-1} \mathrm{ha}^{-1} \mathrm{yr}^{-1}\right) \text { Costa } \\
\text { Rica: N 66, P 2, K 44; } \\
\text { Nicaragua: N 140, P 8, } \\
\text { K } 88\end{array}$ & $\begin{array}{l}\text { Organic-coffee pulp, chicken } \\
\text { manure, lime, rock } \\
\text { phosphate, potassium } \\
\text { sulphate, (mean } \mathrm{kg}^{-1} \mathrm{ha}^{-1} \mathrm{yr}^{-} \\
{ }^{1} \text { ) Costa Rica: N } 248, \mathrm{P} 205, \mathrm{~K} \\
326 \text {; Nicaragua: N 372, P } \\
\text { 179, K 145) }\end{array}$ & $\begin{array}{l}\text { Inorganic fertiliser } \\
\left(\mathrm{kg}^{-1} \mathrm{ha}^{-1} \mathrm{yr}^{-1}\right) \text { Costa Rica: N } \\
\text { 150, P 10, K 75; Nicaragua: } \\
\text { N 78, P 46, K 21) }\end{array}$ & $\begin{array}{l}\text { Inorganic fertiliser } \\
\left(\mathrm{kg}^{-1} \mathrm{ha}^{-1} \mathrm{yr}^{-1}\right) \text { Costa Rica: N } \\
\text { 287, P 20, K 150; } \\
\text { Nicaragua: N 153, P 98, K } \\
\text { 57) }\end{array}$ \\
\hline Disease management & None & $\begin{array}{l}\text { Use of organic and plant } \\
\text { derived substances } \\
\text { dependent on disease } \\
\text { incidence }\end{array}$ & $\begin{array}{l}\text { Use of up to } 4 \text { inorganic } \\
\text { fungicide applications } \\
\text { dependent on disease } \\
\text { incidence }\end{array}$ & $\begin{array}{l}\text { Regular use of } 3 \text { - } 4 \\
\text { inorganic fungicides } \\
\text { applications }\end{array}$ \\
\hline Insect pest management & $\begin{array}{l}\text { Reducing of "gleaning" } \\
\text { (fallen cherries) after } \\
\text { harvest }\end{array}$ & $\begin{array}{l}\text { Manual removal and use of } \\
\text { organic and plant derived } \\
\text { substances dependent on } \\
\text { disease incidence }\end{array}$ & $\begin{array}{l}\text { Manual removal and use } \\
\text { of up to } 4 \text { inorganic } \\
\text { insecticides dependent on } \\
\text { disease incidence }\end{array}$ & $\begin{array}{l}\text { Manual practices and } \\
\text { regular use of } 3 \text { - } 4 \\
\text { inorganic insecticide } \\
\text { applications }\end{array}$ \\
\hline Weed management & $\begin{array}{l}2-4 \text { routine machete } \\
\text { weedings per year }\end{array}$ & $\begin{array}{l}\text { Manual selective weed } \\
\text { management between rows } \\
\text { and cleaning within the row } \\
\text { area }\end{array}$ & $\begin{array}{l}\text { Selective weed } \\
\text { management between } \\
\text { row and cleaning within } \\
\text { the row area manually and } \\
\text { with herbicide }\end{array}$ & $\begin{array}{l}\text { Soil maintained clear of } \\
\text { weeds with herbicides }\end{array}$ \\
\hline $\begin{array}{l}\text { Average yield ( } \pm \mathrm{SE} \text { ) of coffee } \\
\text { cherries across treatments } \\
\left(\mathrm{t} \cdot \mathrm{ha}^{-1} \cdot \mathrm{yr}^{-1}\right) \text { in Costa Rica / } \\
\text { Nicaragua }\end{array}$ & $4.8( \pm 1.1) / 4.7( \pm 0.7)$ & $6.6( \pm 0.36) / 6.4( \pm 0.4)$ & $7.0( \pm 0.4) / 5.5( \pm 0.3)$ & $9.9( \pm 0.7) / 7.1( \pm 0.8)$ \\
\hline
\end{tabular}

${ }^{1}$ Quantities of soil amendments and yields are shown as mean values of known amounts applied annually over seven years. 


\subsection{Statistical analysis}

To investigate the relationship between main-plot and sub-plot treatment effects on individual CFs in the experiment we fitted linear mixed effects models in R (R Development Core Team, 2010) using the Ime4 package (Bates et al., 2011). Main-plot/sub-plot treatment combinations were fitted as a factor with 15 levels for each country (model 1: fixed effects = main-plot + sub-subplot; model 2: fixed effect = main-plot; model 3: fixed effect $=$ sub-plot). Results were assessed using the Akaike Information Criterion (AIC, Burnham and Anderson, 1998), and the model presenting the smallest AIC selected.

\section{Results}

\subsection{Carbon footprinting of different management systems}

The best fitting model for predicting carbon footprints from the main-plot and sub-plot treatments of the experiments is model 3 based on only sub-plot treatments as a fixed effect with random slope effects of replicate blocks and main-plot treatments nested within replicate blocks (the AIC values for this model for Costa Rica and Nicaragua were respectively -32.4 and -66.0 ; in comparison those for model 1 were -13.6 and -49.5 , and for model 2 were -4.0 and -35.6 respectively). This shows that management system and input level (the sub-plot treatment) accounts for most variation in CFs amongst the treatments in the experiment with little remaining variation explained by shade type (the main-plot treatment). This is reflected in their relative coefficients of variation between treatment mean values ( $C V$ is 0.17 and 0.18 amongst the sub-plot treatments and only 0.03 and 0.08 amongst the main-plot treatments for Costa Rica and Nicaragua respectively). Interactions between main-plot and sub-plot treatments cannot be tested separately for each of the experiments as a whole because of the incomplete factorial design. Therefore, results presented here are largely aggregated at the sub-plot level (Figure 1 and Table 4). Nonetheless, for both countries, based on non-overlap of $84 \%$ confidence intervals of sub-plot intercepts for the best-fit model (Payton et al., 2003), there were no significant differences at the $p<0.05$ level amongst the sub-plot treatments (Figure 1). However, in Costa Rica there was a notable trend in the association of CF with management type (conventional versus organic) 
followed by input level, with the conventional intensive (Cl) treatment showing the highest mean CF, followed by conventional moderate (CM), then organic intensity (OI) and finally organic moderate (OM). In Nicaragua, the positive association with level of inputs was dominant over management type: the highest mean $\mathrm{CF}$ was again shown by the $\mathrm{Cl}$ sub-plot treatment, but it was followed by $\mathrm{OI}$, and then $\mathrm{CM}$ and, again last, OM.

a) Costa Rica

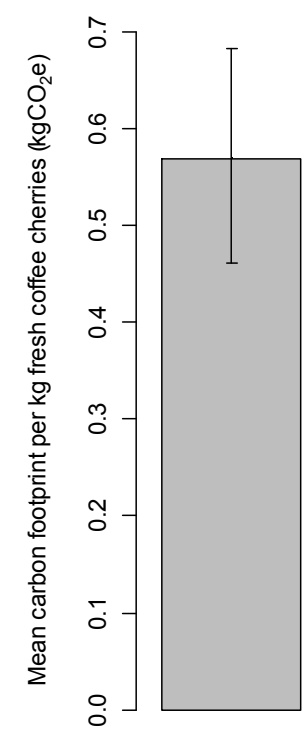

$\mathrm{Cl}$

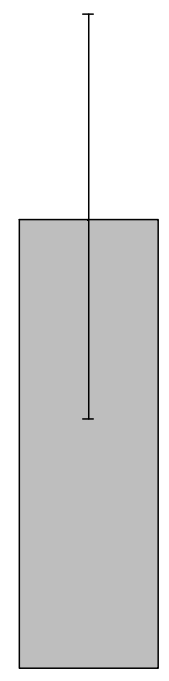

CM

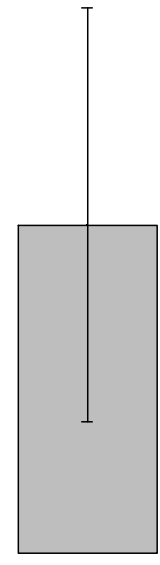

OI

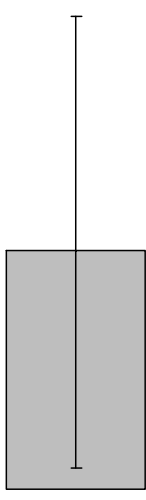

$\mathrm{OM}$ b) Nicaragua

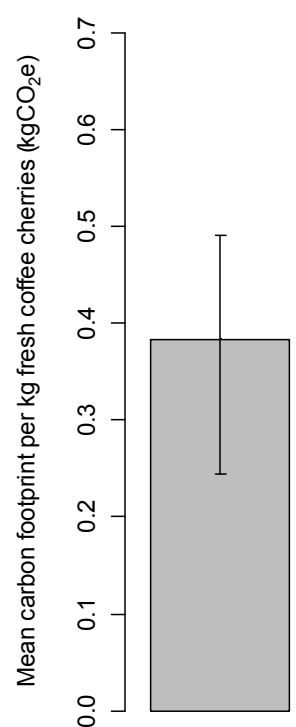

CI

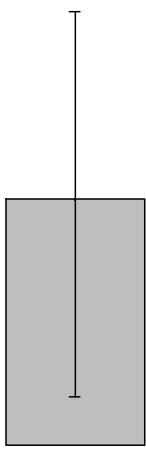

$\mathrm{CM}$

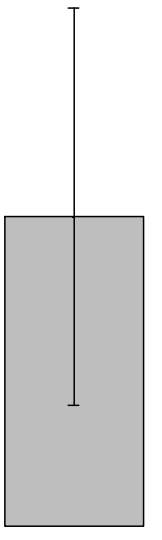

OI

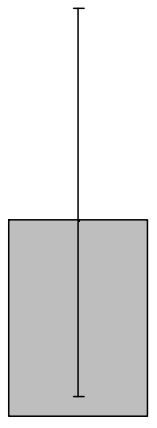

OM
Subplot treatment

Figure 1 Mean coffee product carbon footprints based on model predictions for four sub-plot treatments across five main-plot shade treatments and three replicate blocks in a) Costa Rica and b) Nicaragua. Conventional intensive (Cl); Conventional moderate (CM); Organic intensive (OI); Organic moderate (OM). The bars represent the mean CF per kg of fresh coffee cherries (kgCO2e); whiskers indicate the upper and lower boundaries of the $84 \%$ confidence interval values (appropriate for judging significance of differences at $p<0.05)$.

Direct and indirect soil $\mathrm{N}_{2} \mathrm{O}$ emissions account for a high proportion of the total product $\mathrm{CF}$ (average of $67 \%$ across treatments) and are therefore highly correlated with total CF for both conventional and organic management systems (Figure 2). These emissions result from inorganic and organic fertilisers and from pruned material from coffee bushes and shade trees (Appendix Tables 1 and 2). Nitrogen inputs vary considerably across the main-plot/sub-plot treatment combinations due to variation in 
pruning inputs from shade trees and in coffee bush management (Tables 2 and 3). The significantly steeper (CF/soil $\mathrm{N}_{2} \mathrm{O}$ emissions) slope of the conventional than organic treatments is due to the fact that soil $\mathrm{N}_{2} \mathrm{O}$ emissions form a greater proportion of the $\mathrm{CF}$ for the organic treatments.

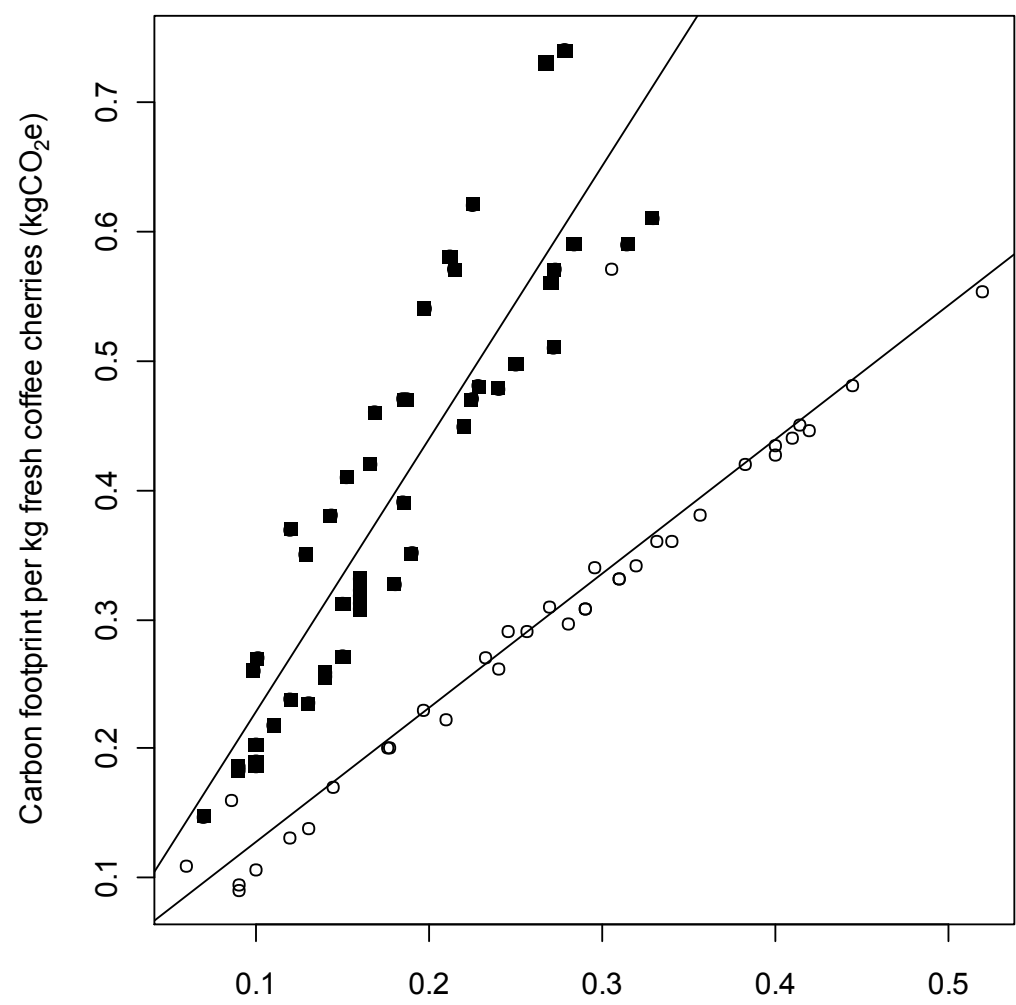

Soil $\mathrm{N}_{2} \mathrm{O}$ emissions per $\mathrm{kg}$ of fresh coffee cherries $\left(\mathrm{kgCO}_{2} \mathrm{e}\right)$

Figure 2 Relationship between soil $\mathrm{N}_{2} \mathrm{O}$ emissions (direct and indirect) resulting from applications of organic and inorganic $\mathrm{N}$ in fertiliser and prunings and the overall carbon footprint of conventional ( - ) and organic $\left({ }^{\circ}\right)$ coffee management treatments in Costa Rica and Nicaragua. Fitted lines: $y_{\text {conventional }}(\mathrm{CF})$ $=0.031+2.03 x\left(\mathrm{kgCO}_{2} \mathrm{e}\right) ; y_{\text {organic }}(\mathrm{CF})=0.007+1.11 x\left(\mathrm{kgCO}_{2} \mathrm{e}\right)$. There was no significant difference between the intercepts but there were significant differences in the slopes between conventional and organic management systems (as judged by the non-overlap of $84 \%$ confidence intervals of sub-plot intercepts for best-fit model predictions), highlighting a significant difference between the two groups.

\subsection{Carbon footprint emission 'hotspots'}

The main CF emission hotspots for the conventional management treatments in both countries were from fertiliser production and direct and indirect soil $\mathrm{N}_{2} \mathrm{O}$ emissions from fertiliser $\mathrm{N}$ inputs (Table 4). Emissions from fertiliser production accounted for $50 \%$ and $45 \%$ of the $\mathrm{Cl}$ and $\mathrm{CM}$ footprints respectively, averaged across both countries. The main CF emission hotspots for the organic 
management treatments were direct and indirect soil $\mathrm{N}_{2} \mathrm{O}$ emissions, resulting from applications of organic fertiliser (such as chicken manure or coffee pulp) and prunings. Soil $\mathrm{N}_{2} \mathrm{O}$ emissions accounted for $92 \%$ and $82 \%$ of the CF for OI and OM treatments respectively, averaged across both countries, in contrast to only $45 \%$ and $47 \%$ for $\mathrm{Cl}$ and $\mathrm{CM}$ treatments respectively. The contribution of $\mathrm{N}_{2} \mathrm{O}$ emissions specifically from pruning inputs varied greatly amongst the four treatments ranging from $7 \%$ in $\mathrm{Cl}$ to 42 $\%$ in OM. The lower yields of coffee cherries with moderate (OM) compared to high input (OI) organic management (Table 3) resulted in soil $\mathrm{N}_{2} \mathrm{O}$ emissions from pruning residues accounting for 1.6 and 1.4 times higher CF per kg of coffee cherry yield in the OM than the Ol treatments in Costa Rica and Nicaragua respectively. Similarly, between the different shade types, in Costa Rica emissions from pruning residues were highest with E. poeppigiana (Appendix Table 1 ) at $0.14 \mathrm{~kg} \mathrm{CO}_{2} \mathrm{e}$ per $\mathrm{kg}$ of coffee cherries (averaged across all sub-plot treatments), followed by mixed legume and timber trees (ET) with $0.08 \mathrm{~kg} \mathrm{CO}_{2} \mathrm{e}$, timber trees $(C, T)$ with $0.01-0.02 \mathrm{~kg} \mathrm{CO}_{2} \mathrm{e}$ and lowest was full sun $(F S)$ at $0.01 \mathrm{~kg} \mathrm{CO}_{2} \mathrm{e}$ (Appendix Table 2). In Nicaragua a similar trend was detected with the highest emissions from pruning residues arising in the mixed legume and timber tree types (ILSG, ILSS) with $0.04-0.05 \mathrm{~kg} \mathrm{CO}_{2}$ e per $\mathrm{kg}$ of coffee cherries followed by timber trees (SGTR, SSTR) with $0.02-0.03 \mathrm{~kg} \mathrm{CO}_{2} \mathrm{e}$ and full sun was again the lowest with $0.02 \mathrm{~kg} \mathrm{CO}_{2} \mathrm{e}$ per functional unit (Appendix Table 2). The main difference in emissions from pruning residues between the countries however is due to the fact that these are smaller in quantity in Nicaragua compared with Costa Rica. A more detailed description of pruning residue inputs within the experiments can be found in Haggar et al. (2011).

\subsection{Impact of different emission factors and the importance of pruning residues}

Nitrous oxide emissions released from soils following the addition of fertilisers are commonly estimated using global, rather than location-specific, EFs. However, soil $\mathrm{N}_{2} \mathrm{O}$ emissions from pruning inputs are often overlooked completely in CF analyses. To explore their impact on system CFs we calculated the mean CF of the four sub-plot coffee management treatments in each country using three different EFs for the soil $\mathrm{N}_{2} \mathrm{O}$ emissions resulting from fertiliser and pruning inputs. Using each of the three different 
Table 4 Mean greenhouse gas emission contributions $\left(\mathrm{kgCO}_{2} \mathrm{e} \cdot \mathrm{t}^{-1}\right.$ fresh cherries, $\left.\pm \mathrm{SE}\right)$ of each emission category to the total product carbon footprint, for the four sub-plot treatments (Conventional intensive (CI); Conventional moderate (CM); Organic intensive (OI); Organic moderate (OM)) for a) Costa Rica and b) Nicaragua. The emissions are shown on a per land area per time basis in Appendix Table 1.

\begin{tabular}{|c|c|c|c|c|c|c|c|c|c|}
\hline Country & $\begin{array}{c}\text { Sub-plot } \\
\text { management } \\
\text { treatments }\end{array}$ & $\begin{array}{l}\text { Fertiliser } \\
\text { production }\end{array}$ & $\begin{array}{l}\text { Pesticide } \\
\text { production }\end{array}$ & $\begin{array}{l}\text { Fuels (used } \\
\text { for non- } \\
\text { transport } \\
\text { purposes) }\end{array}$ & $\begin{array}{l}\text { Materials and } \\
\text { sundries }\end{array}$ & Transport & $\begin{array}{l}\text { Direct/indirec } \\
\text { t soil } \mathrm{N}_{2} \mathrm{O} \\
\text { emissions } \\
\text { from fertiliser } \\
\text { application } \\
\end{array}$ & $\begin{array}{l}\text { Direct/indirec } \\
t \text { soil } \mathrm{N}_{2} \mathrm{O} \\
\text { emissions } \\
\text { from pruning } \\
\text { inputs } \\
\end{array}$ & Total \\
\hline \multirow[t]{3}{*}{ a) Costa Rica } & $\mathrm{Cl}$ & $305( \pm 25)$ & $30( \pm 3)$ & $-{ }^{1}$ & $-^{2}$ & $-^{2}$ & $196( \pm 14)$ & $35( \pm 12)$ & $567( \pm 41)$ \\
\hline & $\mathrm{CM}$ & $227( \pm 13)$ & $13( \pm 1)$ & $19( \pm 1)$ & $-^{2}$ & $-^{2}$ & $152( \pm 9)$ & $50( \pm 14)$ & $463( \pm 29)$ \\
\hline & $\mathrm{OI}$ & $7( \pm 0)$ & 2 & $20( \pm 1)$ & $-^{2}$ & -2 & $244( \pm 15)$ & $69( \pm 18)$ & $345( \pm 27)$ \\
\hline \multirow[t]{4}{*}{ b) Nicaragua } & $\mathrm{Cl}$ & $162( \pm 16)$ & $12( \pm 1)$ & $-^{2}$ & $-^{2}$ & $-^{2}$ & $147( \pm 15)$ & $25( \pm 4)$ & $347( \pm 36)$ \\
\hline & $\mathrm{CM}$ & $103( \pm 6)$ & $13( \pm 1)$ & $-^{2}$ & $-^{2}$ & $8( \pm 8)$ & $93( \pm 6)$ & $36( \pm 4)$ & $255( \pm 18)$ \\
\hline & Ol & $18( \pm 1)$ & $-{ }^{2}$ & $-^{2}$ & $-^{2}$ & $5( \pm 0)$ & $303( \pm 21)$ & $32( \pm 4)$ & $359( \pm 26)$ \\
\hline & OM & 2 & $-^{2}$ & $-^{2}$ & $3( \pm 1)$ & $4( \pm 1)$ & $94( \pm 22)$ & $45( \pm 10)$ & $145( \pm 34)$ \\
\hline
\end{tabular}

${ }^{1}$ In Costa Rica Cl weed control was managed with chemical herbicides applied manually. ${ }^{2}$ Emissions are considered here to be negligible if $<1 \%$ of total CF. Sub-plot treatments in a) Costa Rica ( $\mathrm{Cl}, \mathrm{n}=9 ; \mathrm{CM}, \mathrm{n}=15 ; \mathrm{OI}, \mathrm{n}=12 ; \mathrm{OM}, \mathrm{n}=6)$ and $\mathrm{b})$ Nicaragua $(\mathrm{Cl}, \mathrm{n}=9 ; \mathrm{CM}, \mathrm{n}=15 ; \mathrm{OI}, \mathrm{n}=12 ; \mathrm{OM}, \mathrm{n}=6)$. 
EFs produced a similar trend in CF amongst all four sub-plot treatments in both countries. The greater variation between the EFs for organic (24-244\%) than for conventional (14-40\%) management (Figure 3) was mainly due to the effect of inputs of pruned material.

a) Costa Rica

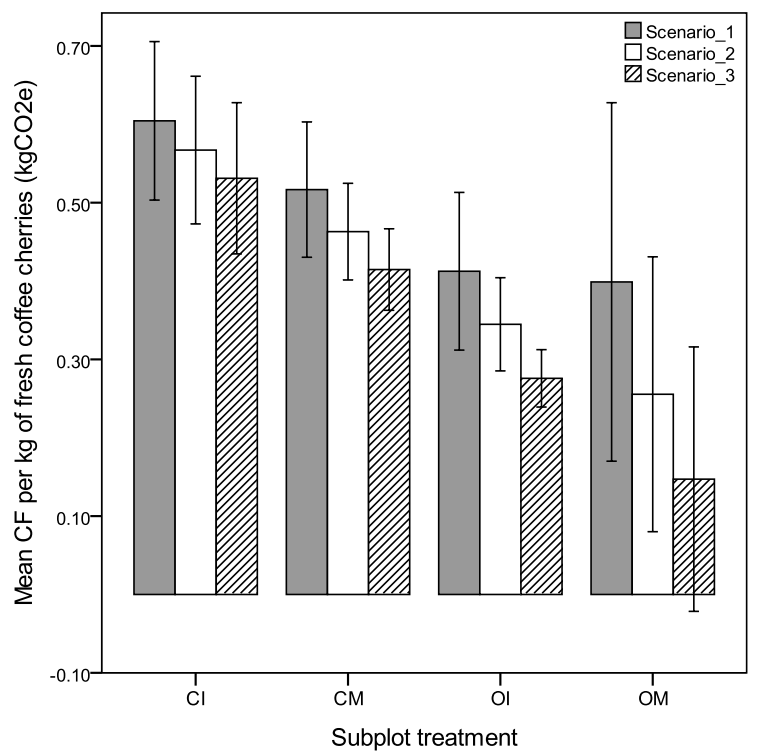

b) Nicaragua

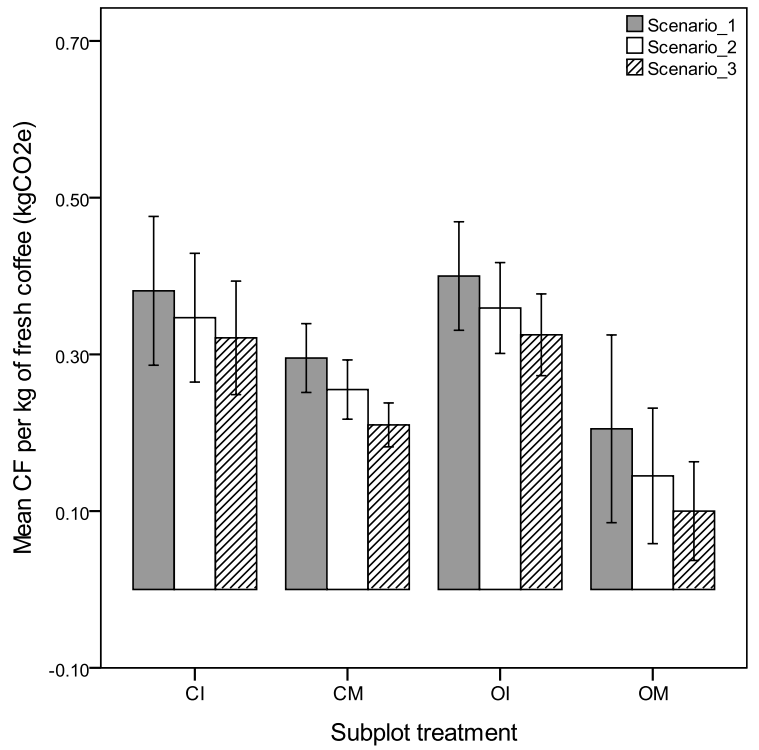

Figure 3 Mean carbon footprint $\left(\mathrm{kgCO}_{2} \mathrm{e}\right)$ for all main-plot treatment $\mathrm{x}$ sub-plot treatment combinations over the three replicate blocks for a) Costa Rica and b) Nicaragua using three different emission factor scenarios (as described in the Methods section); scenario $1(\square)$, scenario $2(\square)$, scenario $3(\nabla)$. Bars represent the mean $\mathrm{CF}$ per $\mathrm{kg}$ of fresh coffee cherries $\left(\mathrm{kgCO}_{2} \mathrm{e}\right)$; whiskers indicate the upper and lower boundaries of the $84 \%$ confidence interval values.

Scenario 1, which is based on IPCC tier 1 global default values for calculating direct and indirect soil $\mathrm{N}_{2} \mathrm{O}$ emissions, does not distinguish between organic, inorganic or pruning/crop residue inputs; it assumes that $1 \%$ of applied $\mathrm{N}$ in all the residues is lost as emissions. Scenario 1 produces a greater mean $\mathrm{CF}$ than that from scenario 2, which uses the region-specific lower value of $0.3 \%$ for the proportion of $\mathrm{N}$ applied to the soil in pruned material that is emitted as $\mathrm{N}_{2} \mathrm{O}$. Scenario 3, which uses the same $\mathrm{N}$ fertiliser EFs as scenario 2 but omits soil $\mathrm{N}_{2} \mathrm{O}$ emissions from pruning inputs, produced the lowest CF across all treatments with the greatest reduction in OM sub-plots. Overall, the choice of EF did not change the rank order of CFs across the four management treatments in either country. However, the effects of EF 
choice are more marked in the organic management treatments because $\mathrm{N}_{2} \mathrm{O}$ inputs from pruning inputs form a comparatively large proportion of their CF. Further, high variability in CF between mainplot shade treatments is observed for both of the organic sub-plot treatments in Costa Rica in the scenario 1 calculations due to the comparatively large contribution to the CF of pruning inputs from the fast-growing leguminous shade tree E. poeppigiana with a $1 \% \mathrm{EF}$.

\section{Discussion}

\subsection{Effect of coffee system management on carbon footprint}

In Costa Rica and Nicaragua together, coffee cultivation covered over 212,000 ha of land in 2010 (FAO 2011), making it a significant contributor to both countries' agricultural GHG balance. Results from this study found that the carbon footprint per $\mathrm{kg}$ of coffee production increased with higher levels of management input in both conventional and organic systems in both the Costa Rican and Nicaraguan experiments. The type of farm management was found by the mixed effects models to account for most variation in CFs. By intensifying coffee farming systems within the experiments, GHG emissions per unit output are increased for conventional and organic treatments.

However, no general conclusion can be made about the comparative CF of organic and conventional systems because the results differed between the two countries. While the organic moderate intensity (OM) treatment had the lowest $\mathrm{CF}$ in both countries, the organic intensive (OI) treatment in Nicaragua had a slightly higher mean CF than the conventional moderate (CM) treatment, whereas in Costa Rica it was lower. This difference between the countries is associated with the variation in local implementation of 'conventional' and 'organic' systems. In Nicaragua, the OI management had higher $\mathrm{N}$ inputs than the three other management systems, whereas in Costa Rica, total inputs of organic and inorganic $\mathrm{N}$ reduced from the $\mathrm{Cl}$ to $\mathrm{CM}$ to $\mathrm{OI}$ to $\mathrm{OM}$ management (Table 3). To determine the effects of organic compared to conventional systems on the carbon footprint it would be necessary to evaluate the $\mathrm{N}$-use efficiency of the two management strategies at the same level of inputs. 
Although the mixed effects model selection procedure showed that shade type had little overall influence on total $\mathrm{CF}$, there were notable differences in the calculated $\mathrm{N}_{2} \mathrm{O}$ emissions associated with their prunings, which were highest from the heavily pruned legume shade trees (Appendix Table 2), even when accounting for the differences in EF used between leguminous and non-leguminous shade (the change in the overall $\mathrm{CF}$ for the highest pruning residue input system $\mathrm{ECl}$ due to a change in $\mathrm{EF}$ from $1.2 \%$ to $1 \%$ of $\mathrm{N}$, is less than $5 \%$ ). Hergoualc'h et al. (2008) concluded that annual $\mathrm{N}_{2} \mathrm{O}$ emissions from a legume-shaded tree system of coffee were 1.3 times higher compared with an un-shaded coffee monoculture. With leguminous shade trees contributing $60-340 \mathrm{~kg} \mathrm{~N} \mathrm{ha}^{-1} \mathrm{yr}^{-1}$ through pruning residues in coffee agroforestry systems (Beer, 1988), the resulting soil $\mathrm{N}_{2} \mathrm{O}$ emissions can account for a significant part of the CF. This is reflected in the present study; relative $\mathrm{N}_{2} \mathrm{O}$ emissions per unit of coffee production from pruning residues were $84 \%$ and $33 \%$ lower for timber shade tree only treatments compared with those using the heavily pruned leguminous shade trees ( $E$ and $I L$ ) in Costa Rica and Nicaragua respectively (Appendix Table 2). For FS treatments the emissions were $92 \%$ and $63 \%$ lower than those with the heavily pruned leguminous trees respectively (Appendix Table 2). This underlines the importance of quantifying the different factors that contribute to overall coffee production system greenhouse gas emissions to provide a broader knowledge base to differentiate the emission factors associated with different $\mathrm{N}_{2} \mathrm{O}$ sources.

\subsection{Emission 'hotspots'}

In the intensive and moderate input organic coffee management treatments in Costa Rica, and all four management treatments in Nicaragua, $\mathrm{N}_{2} \mathrm{O}$ emissions from soil were the greatest emission hotspot. These emissions stem from the application of mineral and organic fertilisers to the soil, and from decomposition of pruning residues where applicable. This is in-line with findings from studies of other crops such as by Plassmann et al. (2010) and Röös et al. (2010) who found that $\mathrm{N}_{2} \mathrm{O}$ emissions form the largest portion of the CF of a sugar cane farm in Mauritius and a potato farm in Sweden, respectively. Despite coffee's global significance economically and agro-ecologically, there appears to be only one 
study published to-date which has analysed the GHG emissions from its cultivation; this pilot study of two coffee estates in Tanzania found that the production and transport of agrochemicals formed over $79 \%$ of the CF of coffee production and primary processing (PCF Pilotprojekt Deutschland, 2008). This is comparable with findings from the intensive and moderate input conventional management systems in Costa Rica in the present study, where fertiliser and pesticide production combined accounted for $\geq 50 \%$ of the CF (Table 4). However, the $\mathrm{N}_{2} \mathrm{O}$ emissions resulting from $\mathrm{N}$ fertiliser application were calculated to be much higher in the present study than those in Tanzania. This may be because the present study includes direct and indirect $\mathrm{N}_{2} \mathrm{O}$ emissions from soils, whereas the Tanzanian pilot study only included direct emissions (PCF Pilotprojekt Deutschland, 2008). Furthermore, for the two organic management systems of the present study, emission hotspots were dominated by release of $\mathrm{N}_{2} \mathrm{O}$ from soils, with virtually no emissions included from fertiliser production because the fertilisers used are by-products or wastes of other industries. Although the organic fertilisers used in these experiments contained relatively small percentages of $\mathrm{N}$, they were applied in large quantities - up to 10 tonnes of chicken manure and 7.5 tonnes of coffee pulp per ha per year in the intensive organic management. As a result, while in the intensive organic treatment soil $\mathrm{N}_{2} \mathrm{O}$ emissions were largely caused by application of these organic fertilisers, in the moderate input organic management, over half the $\mathrm{N}_{2} \mathrm{O}$ emissions resulted from pruning inputs from the shade trees and coffee bushes (Table 4).

There is significant scope for managing farm-level GHG emissions through improved planning of $\mathrm{N}$ application, and this should be seen as a priority by farm extension workers when making recommendations for climate-friendly farming systems. Examples of such GHG-mitigating actions include switching from urea to use of fertilisers with lower rates of nitrification such as ammonium nitrate; improved timing of $\mathrm{N}$ application, taking into account crop requirements, weather patterns and availability of mineral $\mathrm{N}$ in the rooting zone, so that $\mathrm{N}$ is applied at times of greatest demand by the plant; and subsurface application of fertilisers to reduce losses of NO (Matson et al., 1996; Skiba et al., 1997; Smith et al., 1997). However, currently the methods used to calculate the CF would not differentiate between these management practices, and research is needed to quantify their impacts on $\mathrm{N}_{2} \mathrm{O}$ emissions 
and develop appropriate emission factors associated with these practices. Any recommendations requiring capital investment or a change in farming practice will need wider support in order to encourage farmer uptake, and indeed further research on improving the efficiency of both organic and mineral fertiliser use should be seen as a priority in order to determine optimal fertiliser management mechanisms (Tilman et al., 2002).

\subsection{Choice of emission factors}

It is clear from this study that, for coffee production CFs, the accuracy of EFs used to calculate direct and indirect $\mathrm{N}_{2} \mathrm{O}$ emissions from soil is important; within the production systems analysed here, $\mathrm{N}_{2} \mathrm{O}$ emissions formed between $45 \%$ and $92 \%$ of the total CF, making them the single largest source of emissions in the organic management treatments and the second largest emissions source in the conventional treatments. As a result, using different EFs for calculating $\mathrm{N}_{2} \mathrm{O}$ emissions had a large effect on CFs, with CF varying by between $14-244 \%$ depending on the EF used for individual coffee management treatments (Figure 3 ). Three categories of soil $\mathrm{N}_{2} \mathrm{O}$ emissions are commonly accounted for: direct emissions from $\mathrm{N}$-fertilisation of soils, 'secondary' emissions resulting from various transformations of $\mathrm{N}$ compounds, and indirect emissions resulting from leaching and volatilisation of deposited N (Smith et al., 2010). 'Secondary' emissions include those produced by application of crop residues or pruning material, dung and urine from livestock to the soil, and $\mathrm{N}$ mineralisation from soil organic matter and root residues (Smith et al., 2010). In the IPCC tier 1 methodology (scenario 1 in the present study), however, no differentiation is made between direct emissions from $\mathrm{N}$-fertilised soils and secondary emissions from crop residues or pruned material, as both are given the same EF. Further, its value of $1 \%$ for direct $\mathrm{N}_{2} \mathrm{O}$ emissions has a large uncertainty of $30-300 \%$ depending on localised variables such as climate, soil properties and the quality of the incorporated material (De Klein et al., 2006). Therefore, calculating a farm's CF with this global IPCC Tier $1 \mathrm{~N}_{2} \mathrm{O}$ emissions factor can introduce significant error, and indeed its use will not enable the estimation of emission reductions resulting from actions such as improved $\mathrm{N}$ use efficiency, as outlined in section 4.2. 
In tree-based agricultural systems, and in particular in coffee agroforestry systems in which shade-tree prunings contribute a significant proportion of "crop residues", the choice of EF can have a large influence on the overall CF result as shown in Figure 3. Here, we found that the heavily pruned leguminous tree species (E. poeppigiana and I. laurina) had much higher relative emissions from pruning residues per $\mathrm{kg}$ of fresh coffee cherries than other shade types (Appendix Table 2). However, the complexity and interaction of variables influencing soil $\mathrm{N}_{2} \mathrm{O}$ emissions is vast and, because of their major importance for the specification of accurate EFs, they should be a priority for further research to underpin improved carbon footprinting. Factors found to affect $\mathrm{N}_{2} \mathrm{O}$ release from pruning residues include: the presence of $\mathrm{N}$-fixing tree species (Hergoualc'h et al., 2008; Verchot et al., 2008), the quality or chemical composition of plant residues (Seneviratne, 2000; Baggs et al., 2001; Millar and Baggs, 2005) including specifically its C:N ratio (Millar and Baggs, 2004), the interaction between residues and inorganic fertilisers (Frimpong and Baggs, 2010), and the timing of pruning relative to plant nutrient demand and supply (Mosier et al., 2004). However, there is a lack of published literature to enable the accurate calculation of $\mathrm{N}_{2} \mathrm{O}$ emissions from tropical agricultural systems (Matson et al., 1996; Erickson et al., 2001; Mosier et al., 2004) and indeed the IPCC default EF is based heavily on data from temperate and subtropical zones rather than from tropical regions (Stehfest and Bouwman, 2006).

\subsection{Implications for carbon footprinting methodology}

So far, carbon footprinting in agricultural systems has neglected the role of shade trees (often used in coffee cultivation) in sequestering significant amounts of $C$, even beyond the lifetime of the crop. Indeed, carbon storage in living biomass is omitted from the UK carbon footprinting specification, PAS 2050:2008, and its recent revision (October 2011, subsequent to the completion of this study) only gives credit for carbon stored in biomass when that carbon is sequestered as a direct result of land use change occurring in the past 20 years. Importantly, 'land use change' is defined here as a change from one land use type (e.g. forestry) to another (e.g. agriculture), therefore the addition (or removal) of trees within a coffee farm during its lifetime would not be recognised as a form of land use change, thus the resulting change 
to farm GHG balance would not be included in the carbon footprint. In the case of shade-grown coffee, however, trees tend to be planted as a result of coffee farming taking place, thus stored carbon in these systems arises as a direct result of the agricultural production system and should be recognised within the farm GHG balance calculation. To allow for more representative analyses of agricultural systems, a full balance based on emitted and sequestered carbon should be calculated, using the carbon footprinting method followed in this study but including $\mathrm{C}$ sequestration and emissions from biomass and soil. Sequestration of $\mathrm{C}$ in some shade systems could outweigh their emission costs resulting in a net $\mathrm{C}$-balance benefit and potentially making the whole production system carbon neutral over its life span.

\section{Conclusions}

Carbon footprinting enables improved understanding of the most important GHG emission hotspots within a food supply chain. This will help in developing systems which achieve higher agricultural productivity without a proportionate increase in emissions (or lower emissions without a proportionate reduction in productivity). The results of this study highlight the importance of determining which impacts and variables are relevant in calculating the net environmental efficiency of agricultural production systems. While the moderate intensity organic coffee management system had the lowest CF per kilogramme of coffee produced it also had substantially the lowest yield of coffee per hectare. Maintenance of the overall level of production from such systems with low GHG emissions but also low yield per unit area would require conversion of more land to coffee production, locally or elsewhere, but if this land was converted from forest or grassland this would result in additional emissions. This emphasises the potential conflict between increasing food production and creating incentives for climate change mitigation (Angelsen, 2010), which CF methodology needs to encompass.

Identifying emission hotspots through carbon footprinting enables the targeting of farm management recommendations to reduce the impact of agricultural production on GHG emissions. For six of the eight coffee management systems studied here, $\mathrm{N}_{2} \mathrm{O}$ emissions from soil were the greatest contributor to coffee production CFs, for the other two systems fertiliser production made a larger 
contribution. This indicates the value of improvements in fertiliser use efficiency for mitigation of agricultural GHG emissions on coffee farms.

While methodologies such as those of the IPCC are important in standardising estimation of the contribution of overall $\mathrm{N}_{2} \mathrm{O}$ emissions to the $\mathrm{CF}$ for gross system comparisons, in order to compare CFs of different supply chains, accurate emission factors have to be used for each, as demonstrated by the large variability in $\mathrm{CF}$ found when using different EFs for calculating $\mathrm{N}_{2} \mathrm{O}$ emissions. However, for products such as coffee, originating in developing countries, despite their huge global impact, there is a shortage of evidence to enable calculation of EF for different sources and management of nitrogen inputs which are locally specific. Although much has been published on soil $\mathrm{N}_{2} \mathrm{O}$ emissions from agricultural systems, a more detailed understanding of the underlying processes is needed, particularly in tropical regions. Our research supports the conclusions of Smith et al. (2010) that the link between input parameters and release processes is a research priority in order to recommend changes in agricultural management that will reduce emissions. In particular, we recommend new research into the effects of practices aimed to improve $\mathrm{N}$ use efficiency, not only on soil $\mathrm{N}_{2} \mathrm{O}$ emissions, but also nitrogen use efficiency of coffee production.

\section{Acknowledgements}

We thank CATIE for providing and managing the study sites; Mirna Barrios, Elias de Melo, Luis Romero, Elvin Navarette and Ledis Navarette for their great efforts in helping to collect the data for this study; James Gibbons and Aidan Keane for their advice on the statistical analysis; Rodolfo Munguia of the National Agricultural University of Nicaragua (UNA) for his support. This research was funded by a UK Economic \& Social Research Council/Natural Environment Research Council studentship award and a partial fieldwork grant by CAFNET and the Coalbourn Trust to MRAN. 


\section{References}

Althaus, H., Chudacoff, M., Hischier, R., Jungbluth, N., Osses, M., Primas, A., 2007. Life cycle inventories of chemicals. Final report ecoinvent data v2.0 No. 8, Swiss Centre for Life Cycle Inventories, Dübendorf, $\mathrm{CH}$.

Angelsen, A., 2010. Policies for reduced deforestation and their impact on agricultural production. Proc. Natl. Acad. Sci. USA, 107, 19639-19644.

Baggs, E.M., Millar, N., Ndufa, J.K., Cadisch, G., 2001. Effect of residue quality on $\mathrm{N}_{2} \mathrm{O}$ emissions from tropical soils, in: Rees, R.M., Ball, B.C., Campbell, C.D., Watson, R.T. (Eds.), Sustainable management of soil organic matter. CAB International, Oxford, pp. 120-125.

Bates, D., Maechler, M., Bolker, B., 2011. R project. URL http://Ime4.r-forge.r-project.org/

Beer, J., 1988. Litter production and nutrient cycling in coffee (Coffea arabica) or cacao (Theobroma cacao) plantations with shade trees. Agrofor. Syst., 7, 103-114.

Bolwig, S., Gibbon, P., 2010. Product carbon footprinting schemes and standards, in: Gibbon, P., Ponte, S., Lazaro, E. (Eds.), Global Agro-food Trade and Standards: Challenges for Africa, Palgrave Macmillan, London, pp. 21-42.

Brenton, P., Edwards-Jones, G., Jensen, M.F., 2009. Carbon labelling and low-income country exports: a review of the development issues. Dev. Policy Rev., 27, 243-267.

BSI, 2008. PAS 2050: Specification for the assessment of the life cycle greenhouse gas emissions of goods and services. British Standards Institute, London, UK.

Burney, J.A., Davis, S.J., Lobell, D.B., 2010. Greenhouse gas mitigation by agricultural intensification. Proc. Natl. Acad. Sci. USA, 107, 12052-12057. 
Burnham, K., Anderson, D., 1998. Model Selection and Inference: A Practical Information Theoretical Approach. Springer-Verlag, New York.

Classen, M., Althaus, H., Blaser, S., Doka, G., Jungbluth, N., Tuchschmid, M., 2009. Life Cycle Inventories of metals. Final report ecoinvent data v2.1 No.10, Swiss Centre for Life Cycle Inventories, Dübendorf, $\mathrm{CH}$.

De Klein, C., Novoa, R.S.A., Ogle, S., 2006. $\mathrm{N}_{2} \mathrm{O}$ emissions from managed soils and $\mathrm{CO}_{2}$ emissions from lime and urea application. In: IPCC Guidelines for National Greenhouse Gas Inventories, Chapter 11, IGES, Japan.

Dossa, E., Fernandes, E., Reid, W., Ezui, K., 2008. Above- and belowground biomass, nutrient and carbon stocks contrasting an open-grown and a shaded coffee plantation. Agrofor. Syst., 72, 103-115.

Erickson, H., Keller, M., Davidson, E.A., 2001. Nitrogen oxide fluxes and nitrogen cycling during postagricultural succession and forest fertilization in the humid tropics. Ecosystems, 4, 67-84.

FAO, 2011. FAOSTAT: Land-use statistics. Food and Agricultural Organization Rome, Italy.

Foresight, 2011. The future of food and farming. Final project report. The Government Office for Science, London, UK.

Frimpong, K.A., Baggs, E.M., 2010. Do combined applications of crop residues and inorganic fertilizer lower emission of $\mathrm{N}_{2} \mathrm{O}$ from soil? Soil Use. Manage., 26, 412-424.

Haggar, J.P., Barrios, M., Bolaños, M., Merlo, M., Moraga, P., Munguia, R., Ponce, A., Romero, S., Soto, G., Staver, C., Virginio, E. de M. F., 2011. Coffee agroecosystem performance under full sun, shade, conventional and organic management regimes in Central America. Agrofor. Syst., 82, 285-301. 
Hergoualc'h, K., Skiba, U., Harmand, J., Hénault, C., 2008. Fluxes of greenhouse gases from Andosols under coffee in monoculture or shaded by Inga densiflora in Costa Rica. Biogeochemistry, 89, 329-345.

International Institute for Environment and Development (IIED), 1997. Unlocking Trade opportunities: changing consumption and production patterns. Report for the U.N. Department of Policy Coordination and Sustainable Development, pp. 36.

Matson, P.A., Billow, C., Hall, S., Zachariassen, J., 1996. Fertilisation practices and soil variations control nitrogen oxide emissions from tropical sugar cane. J. Geophys. Res. 101, 18533-18545.

Millar, N., Baggs, E.M., 2004. Chemical composition, or quality, of agroforestry residues influences $\mathrm{N}_{2} \mathrm{O}$ emissions after their addition to soil. Soil Biol. Biochem., 36, 935-943.

Millar, N., Baggs, E.M., 2005. Relationships between $\mathrm{N}_{2} \mathrm{O}$ emissions and water-soluble $\mathrm{C}$ and $\mathrm{N}$ contents of agroforestry residues after their addition to soil. Soil Biol. Biochem., 37, 605-608.

Ministerio de Ambiente y Energia, Costa Rica, 2007. Inventario e informe de gases con efecto invernadero (GEI). Estrategia Nacional de Cambio Climatico, Ministerio de Ambient y Energia, Costa Rica.

Mosier, A., Wassmann, R., Verchot, L., King, J., Palm, C., 2004. Methane and nitrogen oxide fluxes in tropical agricultural soils: sources, sinks and mechanisms. Environ. Dev. Sustain., 6, 11-49.

Muschler, R., 2001. Shade improves coffee quality in a sub-optimal coffee-zone of Costa Rica. Agrofor. Syst., 51, 131-139.

Nemecek, T., Kägi, T., Blaser, S., 2007. Life cycle inventories of agricultural production systems. Final report ecoinvent v2.0. 15. Swiss Centre for Life Cycle Inventories, Dübendorf, CH. 
Payton, M.E., Greenstone, M.H., Schenker, N., 2003. Overlapping confidence intervals or standard error intervals: What do they mean in terms of statistical significance? J. Insect Sci., 3:34, Available online: insectscience.org/3.34.

PCF Pilotprojekt Deutschland, 2008. Case study Tchibo Privat Kaffee Rarity Machare by Tchibo GmbH. 1, $1-60$.

Plassmann, K., Norton, A., Attarzadeh, N., Jensen, M.P., Brenton, P., Edwards-Jones, G., 2010.

Methodological complexities of product carbon footprinting: a sensitivity analysis of key variables in a developing country context. Environ. Sci. Policy, 13, 393-404.

R Development Core Team, 2010. R: a language and environment for statistical computing. $R$ Foundation for Statistical Computing, Vienna, Austria. URL http://www.R-project.org/.

Röös, E., Sundberg, C., Hansson, P., 2010. Uncertainties in the carbon footprint of food products: a case study on table potatoes. Int. J. Life Cycle Ass., 15, 478-488.

Segura, M., Kanninen, M., Suarez, D., 2006. Allometric models for estimating aboveground biomass of shade trees and coffee bushes grown together. Agrofor. Syst., 68, 143-150.

Seneviratne, G., 2000. Litter quality and nitrogen release in tropical agriculture: a synthesis. Biol. Fert. Soils, 31, 60-64.

Smith, K.A., McTaggart, I.P., Tsuruta, H., 1997. Emissions of $\mathrm{N}_{2} \mathrm{O}$ and $\mathrm{NO}$ associated with nitrogen fertilization in intensive agriculture, and the potential for mitigation. Soil Use Manage., 13, 296-304.

Smith, K., Crutzen, P., Mosier, A., Winiwarter, W., 2010. The global nitrous oxide budget: a reassessment, in: Smith, K. (Ed.), Nitrous oxide and climate change. pp. 63-84, Earthscan, London, pp. 63-84. 
Smith, P., Martino, D., Cai, Z., Gwary, D., Janzen, H., Kumar, P., McCarl, B., Ogle, S., O'Mara, F., Rice, C., Scholes, B., Sirotenko, O., 2007. Agriculture, in: Metz, B., Davidson, O.R., Bosch, P.R., Dave, R., Meyer, L.A. (Eds.) Climate Change 2007: Mitigation. Contribution of Working Group III to the Fourth Assessment Report of the Intergovernmental Panel on Climate Change. Cambridge University Press, Cambridge, United Kingdom and New York, pp. 498 - 540.

Smith, P., Gregory, P.J., van Vuuren, D., Obersteiner, M., Havlík, P., Rounsevell, M., Woods, J., Stehfest, E., Bellarby, J., 2010. Competition for land. Philos. Trans. R. Soc. Lond. B. Biol. Sci., 365, 2941-2957.

Soil Survey Staff, 1999. Soil taxonomy: a basic system of soil classification for making and interpreting soil surveys. US Department of Agriculture Soil Conservation Service, Washington, DC.

Stehfest, E., Bouwman, L., 2006. $\mathrm{N}_{2} \mathrm{O}$ and $\mathrm{NO}$ emission from agricultural fields and soils under natural vegetation: summarizing available measurement data and modelling of global annual emissions. Nutr. Cycl. Agroecosys., 74, 207-228.

Tilman, D., Cassman, K.G., Matson, P.A., Naylor, R., Polasky, S., 2002. Agricultural sustainability and intensive production practices. Nature, 418, 671-677.

UN, Population Division of the Department of Economic and Social Affairs of the United Nations Secretariat, 2009. World Population Prospects: The 2008 Revision Population Database, New York, USA.

Verchot, L.V., Brienza Júnior, S., de Oliveira, V.C., Mutegi, J.K., Cattânio, J.H., Davidson, E.A., 2008. Fluxes of $\mathrm{CH}_{4}, \mathrm{CO}_{2}, \mathrm{NO}$, and $\mathrm{N}_{2} \mathrm{O}$ in an improved fallow agroforestry system in eastern Amazonia. Agr. Ecosyst. Environ., 126, 113-121.

Verchot, L.V., Hutabarat, L., Hairiah, K., van Noordwijk, M., 2006. Nitrogen availability and soil $\mathrm{N}_{2} \mathrm{O}$ emissions following conversion of forests to coffee in southern Sumatra. Global Biogeochem. Cy., 20, GB4008. 
World Resources Institute \& World Business Council for Sustainable Development, 2009. The Greenhouse Gas Protocol Initiative: Product Life Cycle Accounting and Reporting Standard. Review Draft for Stakeholder Advisory Group, Washington, DC 


